\title{
Does foreign aid contribute to or impeded economic growth?
}

\author{
Thian-Hee Yiew \\ University Tunku Abdul Rahman \\ Malaysia \\ yiewth@utar.edu.my \\ Evan Lau \\ Universiti Malaysia Sarawak (UNIMAS) \\ Malaysia \\ Iphevan@unimas.my
}

\begin{abstract}
This study empirically investigates the role and the impact of foreign aid (ODA) on economic growth (GDP) using 95 developing countries as the sample. Here we also include foreign direct investment (FDI) and population (POP) as the control variables. The panel data results indicate that a U-shape relationship exists between foreign aid and economic growth (Wamboye, 2012; GyimahBrempong and Racine, 2014). Initially, foreign aid negatively impacts the countries' growth and over a period of time, it positively contributes to economic growth. Further, the results strongly support the view that both FDI and POP are more important determinants of GDP, implying that GDP is less likely to depend on ODA. Strengthening the legal framework would be essential for these countries while their overdependency on the influx of ODA might lead to negative impacts on the growth as a whole. Importantly, effective management of foreign aid would ensure the Sustainable Development Goals (SDG) are achieved.
\end{abstract}

Keywords: foreign aid, economic growth, developing countries, panel data.

JEL Classification: F35, O40, C23

\section{INTRODUCTION}

Official development assistance (ODA) or foreign aid has been an important economic growth factor throughout the history. According to (Niyonkuru, 2016), ODA provides assistance to countries' development. These aids may include social infrastructure and economic infrastructure, services' aid and production sector's aid. Social infrastructure in this case includes education, water supply and sanitation, all with the aim to improve human development and eventually contribute to long-term sustainable economic growth (Addison and Tarp, 2015). Besides, economic infrastructure aid does improve energy, transport and 
communications systems in the recipient countries. On the other hand, production sector's aid is aimed for agriculture, forestry and fishing, industry, mining and construction, trade and tourism. It may also attract FDI flows which further contribute positively to the growth. As (Morrissey, 2001: 41) suggests, there can be several positive channels through which ODA impacts economic growth such as "aid increases investment in physical and human capital, aid increases the capacity to import capital goods or technology, aid does not have indirect effects that reduces investments or savings rates, and aid is associated with technology transfers that increase the productivity of capital and promotesendogenous technical change".

The importance of foreign aid was specifically recognized in the Millennium Development Goals (MDGs) initiatives blueprint so that to meet the needs of 148 countries ${ }^{1}$. A $0.7 \%$ ODA/gross national income (GNI) goal was set by the United Nations' decision back in 1970. With this commitment, each advanced country was supposed to progressively increase its ODA assistance to the 148 countries by 2015; however, this goal was not achieved. This was because majority of these countries do not achieve the target of $0.7 \%$. Figure 1 indicates the net ODA in 2015 as percentage of the GNI. The average effort achieved by the donor countries stand at $00.41 \%$ only.

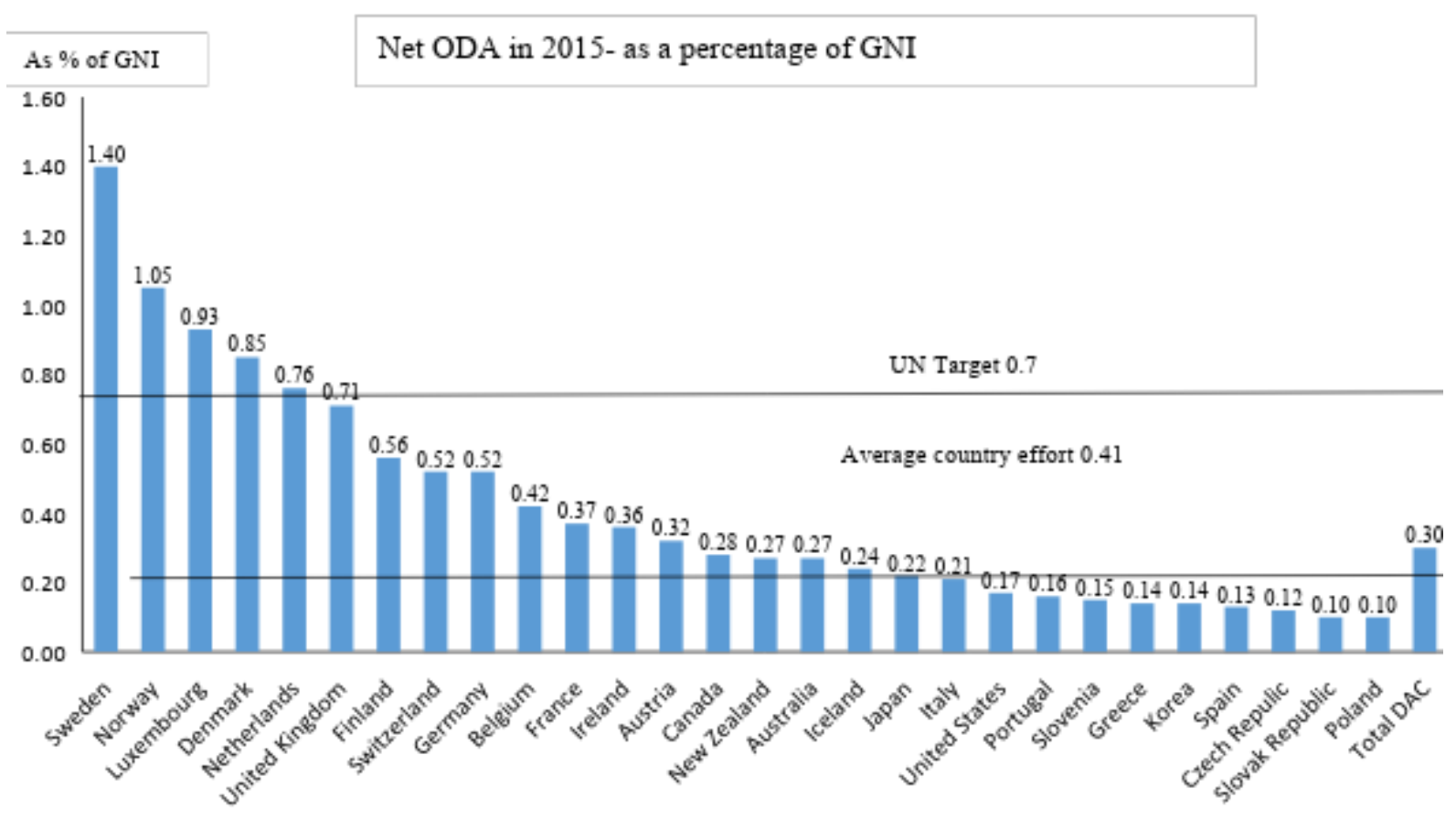

Figure 1. Net ODA in 2015 as a percentage of the GNI

Notes: ODA is official development assistance, GNI is gross national income, DAC is development assistance committee and UN is United Nations.

Source: Organisation for Economic Co-operation and Development (OECD) (2016).

Figure 2 presents the total net ODA from 1960 through 2015. The figure illustrates that the total net ODA increased by 284\% from USD 38192.36 million in 1960 to USD 146676.1 million in 2015. Overall,

\footnotetext{
1 Developing countries are being asked to devise national strategies to meet the MDG targets and to facilitate transparent and accountable governance, while developed countries are being urged to increase aid...... Others have promised to make substantial increases in ODA over the next ten years.” (United Nations, 2005:1).
} 
we observed that the upward trend of the global ODA which in turn do contribute to the economic growth in developing countries (Morrissey, 2001).

Despite the failure in term of achieving the $0.7 \%$ averagely of the ODA, United Nations (2015) listed positive impact of ODA from the perspectives of developing countries. First, ODA contributed to reduce the extreme poverty. The global extreme poverty reduced from 1,926 million in 1990 to 836 million in 2015. Second, the usage of foreign aid was successful in ensuring $91 \%$ of children enroll in primary education for developing countries. Third, the literacy rates increased from 83\% in 1990 to $91 \%$ in 2015. Fourth, the disparities between female and male in education enrolment had been reduced. This generated more girls enroll in school. In Southern Asia, 74 girls were enrolled in primary school for every 100 boys in 1990 and increased to 103 girls were enrolled in primary school for every 100 boys in 2015 . Nevertheless, 90\% countries had more women in parliament after 1995 in supporting the global goals of women empowerment (United Nations, 2015). Fifth, ODA improved the global health issues such as HIV/AIDS, malaria and other diseases. The problem of child dying before age five had been reduce half and this saves 17,000 children per day. Sixth, ODA ensured environmental sustainability of which, for example, people gained access to piped drinking water increased from 2.3 billion in 1990 to 4.2 billion in 2015 (United Nations, 2015). Seventh, ODA reduced child mortality from 90 to 43 deaths per 1000 live births during 1990 and 2015 while global maternal mortality also reduced. Additionally, Gates and Gates (2014) are in support of the continuation of foreign aid as it could save the lives of the poor in particular.

To ensure the continuation of the MDGs, the Sustainable Development Goals (SDGs) was introduced in 2016 based on 17 Global Goals to be achieved by 2030. According to Simpson (2016), these 17 goals require about $\$ 4$ trillion US a year in which more ODA needed if they are to be achieved ${ }^{2}$.

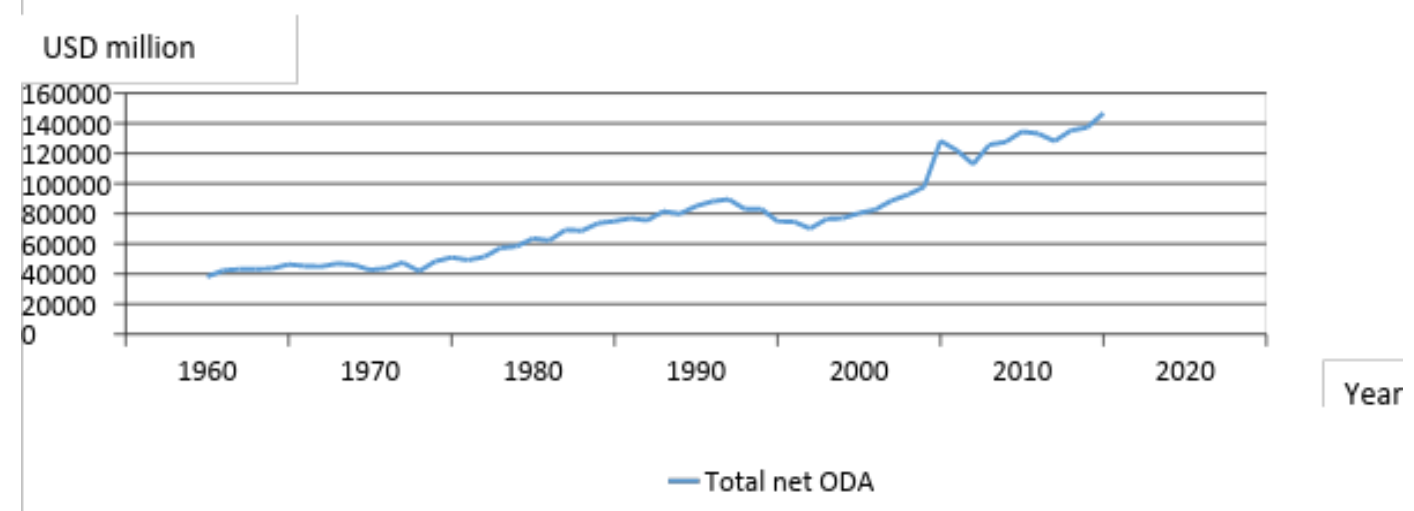

Figure 2. Total net ODA from 1960 through 2015

Note: ODA is official development assistance.

Source: Organisation for Economic Co-operation and Development (OECD) (2016).

Certainly, on the other side of the coin, the debate on ODA also provides negative implication onto the recipient's countries. Among others, Addison and Tarp (2015) and Niyonkuru (2016) present excellent review on the aid management policies. Their study provide arguments that the ODA might come along with hidden agenda from donors while the inefficacy to eradicate poverty was seen as intrinsic to its nature

2 Detail of the 17 Global Goals is made available at http://www.undp.org/content/dam/undp/library/corporate/brochure/SDGs Booklet Web En.pdf 
as results of its mis-management by recipients. This double failure not only creates the notion of ODA exploitations but it also creates a dependency mind-set of those recipient's countries.

From the debate above, one question that needs to be answered is whether foreign aid contributes to or impeded economic growth. With the motivation in hand, we empirically examine the role and impact of ODA on GDP using data for 95 developing countries from 2005 through 2013. We also include foreign direct investment (FDI) and population (POP) as the control variables. This inclusion would answer the question of dependency on ODA for growth impetus. The paper is organized as follows: Section 2 gives a brief review of literature on impact of ODA and growth; Section 3 presents the empirical model and data sources; Section 4 discusses the results while Section 5 contains conclusions and implications of the study.

\section{LITERATURE REVIEW}

A considerable amount of literature has examined the effect of foreign aid on economic growth. Previous researchers that found positive impacts of foreign aid on economic growth (Papanek, 1973; Singh, 1985; Levy, 1988; Burnside and Dollar, 2000; Dalgaard et al., 2004; Gomanee et al., 2005; Karras, 2006; Ndambendia and Njoupouognigni, 2010). Papanek (1973) used a cross country regression to examine the impact of foreign aid on economic growth and found a positive relationship between foreign aid and economic growth. Singh (1985) applied an ordinary least squares (OLS) model to investigate the impact of foreign aid on economic growth. He found that foreign aid contributed to economic growth between 1970 and 1980 in LDC.

Levy (1988) investigated the impact of aid on economic growth in Sub-Saharan African and concluded that a positive relationship exists between aid and economic growth. Burnside and Dollar (2000) suggested that good fiscal, monetary and trade policies had a positive impact on aid and economic growth in developing countries. Using nine years observations, Cungu and Swinnen (2003) applied POLS and fixed effect to examine the impact of aid on economic growth. They found that positive impact between aid and economic growth. Dalgaard et al. (2004) concluded that foreign aid had a positive impact on economic growth, while the magnitude depended on the climate conditions. Analyzing Sub-Saharan African countries, Gomanee et al. (2005) found the same result as Levy (1988). Karras (2006) also found a positive impact of foreign aid on economic growth using data from 1960 through 1997 for 71 developing countries. Using a pooled mean group estimator (PMG), Ndambendia and Njoupouognigni (2010) found a positive impact of foreign aid on economic growth in Sub-Saharan Africa.

Some researchers found that a negative relationship existed between foreign aid and economic growth (Gong and Zou, 2001; Mallik, 2008; Mitra and Hossain, 2013; Mitra et al., 2015). Gong and Zou (2001) found that foreign aid reduced capital accumulation and the labor supply. They suggested that foreign aid would increase the spending of citizens, while foreign aid may create more leisure time for citizens, thus reducing the labor supply. Nevertheless, Mallik (2008) concluded that foreign aid had a negative impact on economic growth in the long run. This results in a "long-term deleterious effect of international aid on living standards". Using the Philippines, Mitra and Hossain (2013) found that increased of $1 \%$ in the foreign aid led to an economic growth decreased of $0.51 \%$. In addition, Mitra et al. (2015) found the negative relationship between foreign aid on economic in short run and long run for 13 Asian economies. They concluded that increased of $1 \%$ in foreign aid led to an economic growth decreased of $0.18 \%$ in Asian economies.

Other researchers found that a relationship between aid and economic growth was insignificant. Mosley et al. (1987) concluded that aid had no impact on economic growth. The results of Boone's (1996) study concurred with that of Mosley et al. (1987). Lensink and Morrissey (2000) found that an insignificant relationship between foreign aid and economic growth existed. 
Liew et al. (2012) applied the pooled ordinary least squares, random effect, and fixed effect models to examine the impact of foreign aid on economic growth in East African countries between 1985 and 2010. They found that a negative relationship existed between foreign aid and economic growth. Dreher and Langlotz (2015) examined the impact of aid and growth using an excludable instrument for 96 countries from 1974 through 2009. They concluded that there was no impact of aid on growth. On the other hand, Galiani et al. (2016) investigated the effect of aid on growth using a quasi-experiment for 35 countries from 1987 through 2010. They found a positive relationship between aid and economic growth. From the literature survey above, one could notice that the impact of foreign aid on economic growth is inconclusive with differences empirical results in terms of data, econometric technique and geographical countries applications.

\section{DATA AND METHODOLOGY}

Data for GDP was obtained from the World Development Indicators (WDI) while FDI, ODA, and POP from the United Nations Conference on Trade and Development (UNCTAD). Data were obtained for the years of 2005 through 2013 (nine years) for 95 developing countries of which the list are made available in the Appendix.

Empirical results from the literature provide indication that the impact of ODA be positive or negative toward GDP. We also include $\mathrm{ODA}^{2}$ to investigate the nonlinear relationship between the ODA and economic growth (Ekanayake and Chatrna, 2010; Clemens et al., 2012; Dreher and Langlotz, 2015) and answering the question of possible U-shape relationship (Wamboye, 2012; Gyimah-Brempong and Racine, 2014). Two control variables (FDI and POP) were included in the estimation model to answer the ODA's dependency notion. FDI measure the external capital (Ndambendia and Njoupouognigni, 2010) where the sign for FDI is expected to be positive. On the other hand, POP measures the labor force in the country (Bloom and Sachs, 1998; Dalgaard et al., 2004). An increase in the labor force is expected to increase economic growth. As such, the sign for POP is expected to be positive.

Prior to the estimation taking place, the GDP, ODA, $O D A^{2}$, FDI and POP variables were transformed into a logarithmic form. The various factors in the model, namely ODA, $O D A^{2}$, FDI and POP have been widely used by previous studies, see among others, Bloom and Sachs (1998), Morrissey (2001), Cungu and Swinnen (2003), Dalgaard et al. (2004), Rajan and Subramanian (2008), Wu and Hsu (2008), Mitra and Hossain (2013) and Galiani et al. (2016). The model is expressed as follows:

$$
G D P=f\left(O D A, O D A^{2}, F D I, P O P\right)
$$

where GDP is the gross domestic product, ODA is the official development aid, ODA ${ }^{2}$ is the official development aid squared, FDI is the foreign direct investment, and POP is the population. Pooled OLS (POLS), Random Effects (RE), Fixed Effects (FE), and Fixed Effect Robust (FERB) regression models were used to examine the impact of foreign aid on economic growth as follows:

$$
G D P_{i t}=\beta_{0}+\beta_{1} O D A_{i t}+\beta_{2} O D A^{2}{ }_{i t}+\beta_{3} F D I_{i t}+\beta_{4} P O P_{i t}+\varepsilon_{i t}
$$

where the index $i=1, \ldots, N$ refers to countries, the index $t=1, \ldots, T$ refers to the period of time, and $\varepsilon_{i t}$ is the error term. Moreover, a Breusch-Pagan Lagrange multiplier (BPLM) test will be applied to evaluate whether the POLS model is suitable for this study. If the results of the BPLM are rejected, POLS is not suitable for this study.

A Hausman test will be used to determine whether RE or FE are the best models for this research. The RE model is as follows:

$$
G D P_{i t}=\beta_{0}+\beta_{1} O D A_{i t}+\beta_{2} O D A^{2} i t+\beta_{3} F D I_{i t}+\beta_{4} P O P_{i t}+\delta_{i}+u_{i t}
$$


where $\delta_{i}$ is the individual specific effect, and $u_{i t}$ is the error term with a normal distribution. The unobservable characteristics will be measured by $\delta_{i}$. The FE model is as follows:

$$
\begin{aligned}
& G D P_{i t}-{\overline{G D P_{l t}}}=\beta_{1}\left(O D A_{i t}-\overline{O D A}_{i t}\right)+\beta_{2}\left(O D A^{2}{ }_{i t}-\overline{O D A}^{2}{ }_{i t}\right)+\beta_{3}\left(F D I_{i t}\right)+ \\
& +\beta_{4}\left(P O P_{i t}-\overline{P O P}_{i t}\right)+\left(u_{i t}-\bar{u}_{i t}\right)
\end{aligned}
$$

If the model transforms into the FE model, the constant and individual effects are eliminated. If the Hausman test concludes the FE model to be the best model, this study will apply the FE robust model to validate the statistical inference. This is because the FE robust model included the robust standard errors. Thus, the FE model will be the final model used in this investigation.

\section{EMPIRICAL RESULTS AND DISCUSSION}

Table 1

Results for the Pooled OLS, Random Effects, Fixed Effects, and Fixed Effects Robust Models Regression

\begin{tabular}{|c|c|c|c|c|}
\hline & Model 1 & Model 2 & Model 3 & Model 4 \\
\hline $\begin{array}{l}\text { Independent } \\
\text { variables: }\end{array}$ & Pooled OLS & Random Effects & Fixed Effects & $\begin{array}{c}\text { Fixed Effects } \\
\text { Robust }\end{array}$ \\
\hline LODA & $\begin{array}{c}-0.726 * * * \\
(-7.53)\end{array}$ & $\begin{array}{c}-0.053^{* * *} \\
(-3.17)\end{array}$ & $\begin{array}{c}-0.051 * * * \\
(-3.06)\end{array}$ & $\begin{array}{c}-0.051 * \\
{[-1.72]}\end{array}$ \\
\hline $\mathrm{LODA}^{2}$ & $\begin{array}{c}0.037 * * * \\
(3.99)\end{array}$ & $\begin{array}{c}0.004^{* * *} \\
(2.78)\end{array}$ & $\begin{array}{c}0.004^{* * *} \\
(2.73)\end{array}$ & $\begin{array}{c}0.004^{*} \\
{[1.82]}\end{array}$ \\
\hline LFDI & $\begin{array}{c}0.122 * * \\
(2.55)\end{array}$ & $\begin{array}{c}0.036 * * * \\
(5.05)\end{array}$ & $\begin{array}{c}0.036 * * * \\
(5.08)\end{array}$ & $\begin{array}{c}0.036 * * * \\
{[2.68]}\end{array}$ \\
\hline LPOP & $\begin{array}{c}1.021 * * * \\
(39.23)\end{array}$ & $\begin{array}{c}0.782^{* * *} \\
(17.84)\end{array}$ & $\begin{array}{c}0.746^{* * *} \\
(7.44)\end{array}$ & $\begin{array}{c}0.746^{* * *} \\
{[3.43]}\end{array}$ \\
\hline CONS & $\begin{array}{c}2.641^{* * * *} \\
(9.76)\end{array}$ & $\begin{array}{c}2.206^{* * *} \\
(5.59)\end{array}$ & & \\
\hline BPLM & \multicolumn{2}{|c|}{$3109.46^{* * *}$} & & \\
\hline Hausman & & \multicolumn{2}{|c|}{$19.76^{* * *}$} & \\
\hline $\mathrm{N}$ & 853 & 853 & 853 & 853 \\
\hline
\end{tabular}
Results

Notes: The figures in parentheses (.) are the $\mathrm{t}$ statisticsand the figures in brackets [.] are the robust standard error. Asterisks ***,**,* denote statistical significance at the 1\%, 5\% and 10\% levels, respectively. LODA is the official development aid, LODA ${ }^{2}$ is the official development aid squared, LFDI is the foreign direct investment, LPOP is the population, CONS is constant and BPLM is Breusch-Pagan Lagrange multiplier.

This paper applies the POLS, RE, FE and FE robust models to examine the impact of ODA on economic growth. The results of the BPLM suggest that POLS is not the best model. Moreover, the Hausman test concluded that the FE is the best model. This study also applied the FE robust model to validate the statistical inference, because the FE robust model included the robust standard error (Liew et al., 2012). Based on this argument, the final results were tabulated in columns 3 and 4.

Surprisingly, the empirical results imply that the ODA has a U-shaped relationship with economic growth. The ODA has a negative relationship with economic growth while $\mathrm{ODA}^{2}$ has a positive relationship with economic growth. The negative impact of ODA and economic growth concurs with the results in the Mallik (2008) and Liew et al. (2012). There are several possible explanations for this result. Firstly, the negative impact of foreign aid on economic growth can be explained as a "bad policy" (Burnside-Dollar, 2000; 
Boone, 1996). This is also in line with the debate from Addison and Tarp (2015) and Niyonkuru (2016) as results of the recipient's countries mis-management of ODA. Secondly, ODA may increase the consumption of the citizen (Boone, 1996; Gong and Zou, 2001), creating more leisure time for the citizen. This leads to a decrease in the labor supply market (Gong and Zou, 2001) and productivity which contributes negatively on growth as a whole. Thirdly, an increase in foreign aid will decrease the capital accumulation and the labor supply in the long run (Liew et al., 2012). They also argued that foreign aid leads to an appreciation in the exchange rate, which affects the balance of payments. This will increase the risk in the economic growth such as export becomes more expensive lead to decrease export. Hence, this will create deficit in these countries.

Looking into the positive impact of $\mathrm{ODA}^{2}$, overtime it may contribute to the development in social infrastructure, economic infrastructure and services and production sector. Thus, the multiple impact of the foreign aid may positively impact the economic growth and create more job opportunities in the market. This will contribute to economic growth in the long run. In other words, putting aids into existing efficient started projects, infrastructure investment, more inclusive and extensive social welfare, empowering the poor would eventually leads to sustainable economic growth. Certainly to do this the recipient's government should practice prudent economic governance that build upon law and regulations in order to allocate the ODA inclusively on the economic sectors.

We found that FDI has a positive impact on economic growth. This indicates that an increase of $1 \%$ in the FDI leads to an economic growth increase of $0.036 \%$; this result was statistically significant in Model 3. This concluded that an increase in FDI leads to an economic growth increase in developing countries (Blomstrom et al., 1992; Balasubramanyam et al., 1996; Borensztein et al., 1998). According to Borensztein et al. (1998), FDI is an important channel to use to transfer technology, which contributes to economic growth. This can transmit the technology in the country and create a spillover effect. Nevertheless, the FDI can bring in foreign capital and encourage economic growth in developing countries.

The empirical results also illustrate that a $1 \%$ increase in the population increases economic growth by $0.746 \%$ in Model 3. This suggests that the population contributes to economic growth in developing countries. A larger population will provide a larger labor force in developing countries. This will contribute to a large market and spur economic growth. Furthermore, the impact of the population is higher than the impact of ODA and FDI. Hence, the population is an important variable for economic growth. Comparatively, the impact of ODA is small to economic growth for 95 countries. This indicates economic growth is less likely depends on ODA for stimulating sustainable growth.

\section{CONCLUSION}

This paper investigated the impact of foreign aid on economic growth. Surprisingly, the relationship presented a U-shape between foreign aid and economic growth using data for 95 developing countries from the years of 2005 through 2013. Moreover, we found positive relationship between the population and foreign direct investment on economic growth. Interestingly, results strongly support the view that both FDI and POP to be more important determinants of GDP, implying that GDP is less likely depends on ODA. This indeed negates the claim on the dependency notion from the recipient's countries onto the donors. This does not imply that aid do not helps growth but rather statistically, it was not the most important determinant of growth for these panel of countries.

This paper suggests that strengthening the law and legal framework would be essential for these countries while over-dependency on influx of foreign aid might leads to negative impact on the growth as a whole. For example, the inclusive distribution of foreign aid should be observed and scrutinized by the government. One future extension of the empirical model would be on the inclusion of the governance and 
its interactive term to provide better understanding of these dynamic interrelationship. Efforts from both parties (the donors and recipients) are important to ensure the management of ODA is effectively implemented to yield fruitful results. Importantly, effective governing of the foreign aid would ensure the aim Sustainable Development Goals (SDG) to be achieved.

\section{ACKNOWLEDGEMENT}

The authors would like to thank the anonymous referees and the editor for their helpful comments and suggestions. Earlier version of the paper was presented at International Conference on Applied Economics and Policy (ICAEP) 2017. The authors gratefully acknowledges financial support from the UNIMAS Geran Penyelidikan Khas (Top Down) 03(TD04)/1054/2013(02). Any remaining errors in this research project will be the responsibility of the authors.

\section{REFERENCES}

Addison, T., \& Tarp, F. (2015). Aid policy and the macroeconomic management of aid. World Development, 69,1-5. https://doi.org/10.1016/j.worlddev.2014.02.009.

Balasubramanyam, V. N., Salisu, M., \& Sapsford, D. (1996). Foreign direct investment and growth in EP and IS countries.Economic Journal, 106, 92-105. https://doi.org/10.2307/2234933.

Blomstrom, M., Lipsey, R., \& Zejan, M. (1992). What explains developing country growth. National Bureau of Economic Research (NBER) working Paper No. 4132. Cambridge.

Bloom, D., \& Sachs, J. D. (1998).Geography, demography and economic growth in Africa. Brookings Papers on Economic Activity, 2, 207-273.

Boone, P. (1996). Politics and the effectiveness of foreign aid. European Economic Review, 40, $289-329$. https://doi.org/10.3386/w5308.

Borensztein, E., De Gregorio, J., \& Lee, J. W. (1998). How does foreign direct investment affect economic growth?. Journal of International Economics, 45, 115-135.

Burnside, C., \& Dollar, D. (2000). Aid, Policies, and Growth. The American Economic Review, 90, 847-868. https://doi.org/10.1257/aer.90.4.847.

Clemens, M., Radelet, S., Bhavnani, R., \& Bazzi, S. (2012). Counting chickens when they hatch: Timing and the effects of aid on growth. Economic Journal, 122, 590-619. https://doi.org/10.1111/j.1468-0297.2011.02482.x

Cungu, A. \& Swinnen, J. F. M. (2003). The Impact of Aid on Economic Growth in Transition Economies: An Empirical Study. Discussion Papers 128/03, Centre for Institutions and Economic Performance, Katholieke Universiteit Leuven. Belgium.

Dalgaard, C. J., Hansen, H., \& Tarp, F. (2004).On the empirics of foreign aid and growth. The Economic Journal, 114, 191-216. doi: 10.1111/j.1468-0297.2004.00219.x.

Deaton, A. (2013). The Great Escape: Health, Wealth, and the Origins of Inequality, Princeton University Press, Princeton, NJ.

Dreher, A., \& Langlotz, S. (2015). Aid and growth. New evidence using an excludable instrument. CEPR Discussion Paper 10811. Heidelberg.

Ekanayake, E. M., \& Chatrna, D. (2010).The effect of foreign aid on economic growth in developing countries. Journal of International Business and Cultural Studies, 3, 1-13.

Galiani, S., Knack, S., Xu, L. C., \& Zou, B. (2016). The effect of aid on growth: evidence from a quasi-experiment. National Bureau of Economic Research (NBER) Working Paper No. 22164. Cambridge.

Gates, B. \& Gates, M. (2014). Three Myths on the World's Poor. Wall Street Journal, January 17, 2014. Retrieved from http://online.wsj.com/news/articles/SB10001424052702304149404579324530112590864.

Gomanee, K., Girma, S., Morrissey, O. (2005). Aid and growth in sub-Saharan Africa: Accounting for transmission mechanisms. Journal of International Development, 17, 105-1075. https://doi.org/10.1002/jid.1259

Gong, L., \& Zou, H. F. (2001). Foreign aid reduces labor supply and capital accumulation. Review of Development Economics, 5, 105-118. 
Gyimah-Brempong, K., \& Racine, J. S. (2014). Aid and economic growth: A robust approach. Journal of Africa Development, 16, 1-35.

Karras, G. (2006). Foreign aid and long run economic growth: Empirical evidence for a panel of developing countries. Journal of International Development, 18, 15-28. https://doi.org/10.1002/jid.1187.

Papanek, G. (1973). Aid, private foreign investment, savings and growth in less developed countries. Journal of Political Economy, 81, 120-130. https://doi.org/10.1086/260009

Lensink, R., \& Morrissey, O. (2000).Aid instability as a measure of uncertainty and the positive impact of aid on growth. Journal of Development Studies, 36, 31-49.

Levy, V. (1988). Aid and growth in sub-Saharan Africa: the recent experience. European Economic Review, 32, 1777-1795. https://doi.org/10.1016/0014-2921(88)90085-2.

Liew, C. Y., Mohamed, M. R., \& Mzee, S.S. (2012). The impact of foreign aid on economic growth of East African countries. Journal of Economics and Sustainable Development, 3, 129-138.

Mallik, G. (2008). Foreign aid and economic growth: A cointegration analysis of the six poorest African countries. Economic Analysis and Policy, 38, 251-260. https://doi.org/10.1016/S0313-5926(08)50020-8

Mitra, R., \& Hossain, M. S. (2013). Foreign aid and economic growth in the Philippines. Economics Bulletin, 33, 17061714.

Mitra, R., Hossain, M. S., \& Hossain, M. I. (2015). Aid and per-capita economic growth in Asia: A panel cointegration tests. Economics Bulletin, 35, 1693-1699.

Morrissey, O. (2001). Does aid increase growth?. Progress in Development Studies, 1, 37-50. https://doi.org/10.1191/146499301701571354

Mosley, P., Hudson, J., \& Horrell, S. (1987). Aid, the public sector and the market in less developed countries. Economic Journal, 97, 616-641.

Ndambendia, H., \& Njoupouognigni, M. (2010). Foreign aid, foreign direct investment and economic growth in subsaharan Africa: Evidence from Pooled Mean Group Estimator (PMG). International Journal of Economics and Finance, 2, 39-45.

Niyonkuru, F. (2016). Failure of foreign aid in developing countries: A quest for alternatives. Business and Economics Journal, 7, 1-9. https://doi.org/10.4172/2151-6219.1000231

Organisation for Economic Co-operation and Development (OECD).(2016). Net ODA. Retrieved November 30 , 2016, from https://data.oecd.org/oda/net-oda.htm\#indicator-chart

Ravallion, M. (2014). On the role of aid in The Great Escape. Review of Income Wealth, 60, 967-984.

Rajan, R., \& Subramanian, A. (2008). Aid and growth: what does the cross-country evidence really show?. Review of Economics and Statistics, 90, 643-665.

Simpson, E. (2016). Sustainable development goals worth sharing. Political Science Publications. Paper 130.

Singh, R. (1985). State intervention, foreign economic aid, savings, and growth in LDCs: some recent evidence. Kyklos, 38, 216-232. https://doi.org/10.1111/j.1467-6435.1985.tb02224.x.

United Nations (2005). 2005 World Summit: An overview. 2005 World Summit.

United Nations (2015). The Millennium development goals report 2015. New York, NY: United Nations.

World Health Organization (2017). UN sustainable development summit 2015: Sustainable Development goals. Retrieved May 26, 2017, from http://www.who.int/mediacentre/events/meetings/2015/un-sustainable-developmentsummit/en/

Wamboye, E. (2012). Quantity or quality? Foreign aid implications on economic growth in least developed countries. Munich Personal RePEc Archive (MPRA) paper 39518, University Library of Munich, Germany.

Wu, J. Y., \& Hsu, C. C. (2008). Does foreign direct investment promote economic growth? Evidence from a threshold regression analysis. Economics Bulletin, 15, 1-10. 
APPENDIX: LIST OF COUNTRIES

\begin{tabular}{|c|c|c|c|c|}
\hline Afghanistan & $\begin{array}{l}\text { Central African } \\
\text { Republic } \\
\end{array}$ & Guatemala & Maldives & Solomon Islands \\
\hline Albania & Chile & Guinea & Mali & Sri Lanka \\
\hline Algeria & Colombia & Guinea-Bissau & Mauritius & Sudan \\
\hline Anguilla & Comoros & Guyana & Mexico & Tajikistan \\
\hline Antigua and Barbuda & Congo & Haiti & Morocco & Togo \\
\hline Argentina & Costa Rica & Honduras & Mozambique & Tunisia \\
\hline Armenia & Côte d'Ivoire & India & Myanmar & Uganda \\
\hline Bangladesh & $\begin{array}{l}\text { Dem. Rep. of the } \\
\text { Congo }\end{array}$ & Iran & Namibia & Ukraine \\
\hline Belarus & Djibouti & Iraq & Nicaragua & $\begin{array}{l}\text { United Republic of } \\
\text { Tanzania }\end{array}$ \\
\hline Belize & Dominica & Jordan & Niger & Uruguay \\
\hline Benin & Dominican Republic & Kazakhstan & Nigeria & Uzbekistan \\
\hline Bhutan & Ecuador & Kenya & Pakistan & Vanuatu \\
\hline $\begin{array}{l}\text { Bosnia and } \\
\text { Herzegovina }\end{array}$ & Eritrea & Kyrgyzstan & Palau & Viet Nam \\
\hline Botswana & Ethiopia & $\begin{array}{l}\text { Lao People's Dem. } \\
\text { Rep. }\end{array}$ & Paraguay & Zambia \\
\hline Brazil & Fiji & Lebanon & Rwanda & Zimbabwe \\
\hline Burkina Faso & Gabon & Lesotho & Samoa & \\
\hline Burundi & Gambia & Liberia & \multicolumn{2}{|c|}{ Sao Tome and Principe } \\
\hline Cambodia & Georgia & Libya & Senegal & \\
\hline Cameroon & Ghana & Madagascar & Seychelles & \\
\hline Cabo Verde & Grenada & Malawi & Sierra Leone & \\
\hline
\end{tabular}

